\title{
Science Literacy: Hand in Glove with Numeracy
}

Gerry G. Meisels

University of South Florida,Tampa, meisels@csl.usf.edu

Follow this and additional works at: https://digitalcommons.usf.edu/numeracy

Part of the Mathematics Commons, and the Science and Mathematics Education Commons

\section{Recommended Citation}

Meisels, Gerry G.. "Science Literacy: Hand in Glove with Numeracy." Numeracy 3, Iss. 2 (2010): Article 1. DOI: http://dx.doi.org/10.5038/1936-4660.3.2.1 


\title{
Science Literacy: Hand in Glove with Numeracy
}

\begin{abstract}
Science Literacy requires numeracy as part of its foundation, and much of Numeracy draws on examples and applications from the sciences. They share the goal of creating a society that is mathematics numerate and science literate, and are interrelated. National priorities to strengthen both among all our students are driven by practical considerations of economic competitiveness that increasingly depend on technological innovation. It is also critical to each individual for long-term job opportunities and for informed citizenship. With up to $80 \%$ of 21 st century jobs requiring mathematics and science skills, a large majority of the 2,900,000 students who graduate from America's high schools every year must become Numerate and Science Literate. Many of these students are not motivated to learn, requiring a change in teaching strategies. Societal will and substantial resources are required to help teachers adopt new approaches that are much more demanding than traditional lectures. Major organizational changes may be needed to strengthen student experience in elementary schools. Advocates of Numeracy and Science Literacy need to work hand in glove to create a citizenry prepared to compete in the 21 st century.
\end{abstract}

\section{Keywords}

science literacy

Creative Commons License

$$
\text { (c) (1) (8) }
$$

This work is licensed under a Creative Commons Attribution-Noncommercial 4.0 License

\section{Cover Page Footnote}

Gerry Meisels, a chemist, is Director of the University of South Florida Coalition for Science Literacy. He has published over 100 papers on his research in Mass Spectrometry and Radiation Chemistry. He is a former Dean of the College of Arts and Sciences at the University of Nebraska-Lincoln and former Provost and Vice President for Academic Affairs at the University of South Florida. For twelve years he served on the Council of Scientific Society Presidents, including a term as Council Chair. His current work focuses on implementing large-scale science/mathematics education reform. 
Contemporary concepts of Science Literacy take a very broad view. They emphasize a person's commitment to evidence-based argumentation, and to a basic understanding of the nature of science and its processes. Most importantly, today's approach gives high priority to the ability to think and reason analytically and inductively. A large part of scientific reasoning relies on quantitative relationships such as those expressed in the laws of nature that concisely summarize observations. The core objective of science literacy is almost identical to that of numeracy "to reason with numbers and other mathematical concepts" and "to be comfortable with logic and reasoning." "The goals of creating a society that is mathematics numerate and science literate not only overlap to a substantial extent, they are interrelated: science literacy requires numeracy as part of its foundation, and much of numeracy draws on examples and applications from the sciences.

Over the last two decades, the need for our society to have a strong command of Numeracy and Science Literacy (NSL) has received increased attention and led to a sense that we need urgent action to improve them. The three prongs underlying this increased emphasis for our people and especially our schools are (1) the need for a workforce that is able to work effectively in an increasingly technology-based environment, (2) the need for more specialists in the STEM (Science, Technology, Engineering and Mathematics) disciplines, and (3) the dismal results of international comparisons of student performance in science and mathematics such as TIMSS $^{2}$ and PISA. ${ }^{3}$ What makes all this so important to America is that NSL is essential to the future of our country's competitiveness in the international economy. ${ }^{4}$ Our economic leadership has resulted from innovation which cannot be sustained without the STEM professionals who are at the core of creating technological innovation, and the large number of others whose NSL skills support implementation of innovations.

The benefit of NSL accrues not only to the macroscopic terms of international competition, but also to the fate and welfare of individuals. NSF

\footnotetext{
${ }^{1}$ Definition from Wikipedia, June 21, 2010.

${ }^{2}$ Trends in International Mathematics and Science Study (TIMSS). Washington DC: National Center for Education Statistics, 2007. http://nces.ed.gov/timss/results07.asp last accessed June 21, 2010.

${ }^{3}$ Program for International Student Assessment (PISA), 2006. Washington DC: National Center for Education Statistics, 2006. http://nces.ed.gov/surveys/pisa/ last accessed June 21, 2010.

${ }^{4}$ Rising above the Gathering Storm. Committee on Science, Engineering, and Public Policy (COSEPUP), Washington DC: National Academy Press, 2007. http://www.nap.edu/openbook.php?isbn=0309100399 last accessed June 21, 2010

The Opportunity Equation. Transforming Mathematics and Science Education for Citizenship and the Global Economy, New York NY: Carnegie Corporation, June 2009. http://www.opportunityequation.org/the-report/executive-summary/ last accessed June 21, 2010.
} 
data show that $80 \%$ of the workforce of the future will require use of Science and Engineering skills closely or at least somewhat, in both STEM and Non-STEM jobs. ${ }^{5}$ This is in sharp contrast to conditions 50 years ago when only $32 \%$ of the workforce required such skills. ${ }^{6}$ Similarly, the need for unskilled labor was about $60 \%$ in 1950 , but only $15 \%$ in 1997 . Young people who do not possess NSL skills are largely precluded from competing for a substantial majority of jobs, and what is equally important, they are not prepared with the fundamental skills that are transferable from job to job as different technologies come and go. It was only a few years ago that Orlando was home to a microchip industry that employed several thousand workers. Within a period of only two years the factories were shuttered. Laid-off employees with NSL skills could be retrained quickly; others were not so fortunate.

There is no doubt that satisfying and well-paying jobs are available in many different fields. In theater, TV, other performance professions, and sports, the income of the most successful practitioners is staggering by most people's standards. However, the aspiring youngster's probability of reaching that level is extremely small, and often at risk because accidental injuries that may be minor to others may derail pursuit of their dream. Those who do not have good fortune have little on which they can fall back. For them and for all others, Numeracy and Science Literacy are the gatekeepers to their personal and professional futures. My personal observations have convinced me that these are the great dividing line for most people: those who can handle numbers and reason logically have options and can advance, while the vast majority of those who cannot are destined to sub- and para-professional functions that provide jobs and a living, but offer little hope for growth and advancement.

NSL's importance goes well beyond the economy and individual competitiveness in the job market. It is equally critical to understanding contemporary issues and the news, to personal decision-making, and to responsible citizenship. For example, we are overwhelmed with advertisements by pharmaceutical companies, and most medical procedures and treatments cite percentage success or risk figures. Their interpretation requires both a rudimentary understanding of statistics and probability, and the ability to ask for and understand the measures and the evidence on which they are based. NSL also underlies an understanding of numerous policy issues, from national health insurance plans to disaster relief and safety.

\footnotetext{
${ }^{5}$ Vazquez, J. A. Presentation at the Florida Summit on Science and Mathematics Education, Tampa, FL, 2005; Calculated from Science and Engineering Indicators 2002 Text Tables 3-1, 32, pages 3-6, 3-7. Arlington VA: National Science Foundation.

${ }^{6}$ Ibid.
} 
We should do our best to assure NSL of every high school graduate. While this has been declared a national priority by the current administration, achieving it in practice will require a great deal of commitment and the will of all sectors of our society: political, business/industry, education administration, and individuals, especially parents. In large part the challenge is so great because we can no longer focus just on the best and brightest, the top 20\%, but must reach the vast majority, $80 \%$ of the $2,900,000$ that graduate from high schools annually. ${ }^{7}$ A majority of the students we must reach are not highly motivated to learn-they reflect the basic characteristics of our society whose senses are constantly bombarded with hyped-up advertising messages. Contrary to half a century ago, we must now "sell" education to our students.

Because student motivation to learn can no longer be presumed for a majority of those who must become mathematics and science literate, it must be developed by teachers and parents. That requires an entirely different and much more challenging style of teaching than the traditional lecture format. While colleges of education are gradually moving to produce graduates prepared to teach in that mode, a majority of secondary school teachers in mathematics and the sciences is drawn from alternative entrants. These come to teaching after practicing in one of the professions such as accounting. Many tend to teach as they were taught by college faculty - in the lecture mode. Large-scale and thus costly programs are needed to assist current and incoming teachers to work with their students differently.

The challenge is perhaps even greater at the elementary school level where teachers' focus is more on the child than the subject. Many elementary teachers find mathematics and science difficult and therefore may teach them in a way that signals teachers' apprehensions. That transmits "negative vibes" to their students and discourages them. Professional development of a million and a half elementary teachers would be a truly massive and costly task that would have little chance of changing basic attitudes. Fortunately, alternate methods of addressing the needs at this level, such as departmentalization, coaches, and specialists, are now being explored ${ }^{8}$ but their efficacy is not yet established.

Numeracy and Science Literacy are not only interdependent and share many objectives, they also face very similar problems in achieving the similar outcomes. It is in the best interest of both to work together closely and support each other whenever there is an opportunity for one or the other.

\footnotetext{
7 The Condition of Education 2010. Washington DC: National Center for Education Statistics. http://nces.ed.gov/pubs2010/2010028.pdf last accessed June 21, 2010
}

8 See Science Educator, Volume 17 No. 2 (Fall 2008), which includes several articles. 